\title{
Analysis of Implied Meaning of Color Terms in the Novel The Masque of the Red Death from the Perspective of "Effect Theory"
}

\author{
Siyou Zhang ${ }^{1}$, Zhongwen $\mathrm{Pei}^{1}$, Jiangyu Sun ${ }^{1}$ \\ ${ }^{1}$ Wuhan University of Science and Technology, Wuhan, Hubei Province, China
}

Keywords: Edgar Allan Poe; Effect Theory; The Masque of the Red Death; color words; terror; death.

\begin{abstract}
Edgar Allan Poe is a famous American novelist. Poe is best known for his mystery stories and horror stories, and is recognized as "the inventor of science fiction". Edgar Allan Poe put forward the famous "Effect Theory", emphasizing that the main purpose of literary creation is to impress readers. This paper analyzes the effects of color words in the short story The Masque of the Red Death from the perspective of Effect Theory, and points out its practical significance to modern society.
\end{abstract}

\section{Effect Theory}

Effect Theory is proposed by Edgar Allan Poe, a famous American writer. Poe is one of the most famous writers in American literature. British literary giant Bernard Shaw once claimed that America had bred two magnificent authors, Edgar Allan Poe and Mark Twain. Poe is one of the few literature notabilities who can write and comment at the same time. He can realize the "music beauty" he proposed in poems like Annabel Lee and The Raven, and fulfill the "Effect Theory" in short stories like The Masque of the Red Death.

When discussing poems created by Longfellow, Poe said, "readers' soul is never deeply moved, and they do not care about distorted information anymore." [1] In other words, the purpose of literary creation is to impress readers as deeply as possible. As long as the task is completed, authors achieve the effect of literary creation. They do not need to feel ashamed for their strange writing methods, or the grotesque beauty expressed in their works. In a word, literary works should be created to impress readers' mind, and achieve certain effects. Poe always advocates "arts for arts' sake". In his article In Review of Hawthorne-Twice Told Stories, Poe puts forward to the famous "Effect Theory", which serves as a summary of his proposition. Specifically speaking, Effect Theory includes the following points. 1 . Before writing, the author should determine a certain unique or single effect, then invents and combines incidents to establish this preconceived effect. 2 . The very initial sentence should bring out this effect. 3. In the whole composition, every details and sentences should contribute to the pre-established effect.

\section{Effects of Color Words in The Masque of the Red Death}

As one of his best short stories, The Masque of the Red Death was created according to Poe's view on literary creation. "A skilful literary artist has constructed a tale. If wise, he has not fashioned his thoughts to accommodate his incidents; but having conceived, with deliberate care, a certain unique or single effect to be wrought out, he then invents such incidents - he then combines such events as may best aid him in establishing this preconceived effect." [2]

The novel described a story about death and human nature. Prince Prospero attempted to avoid a dangerous plague, known as the Red Death, by hiding in his abbey. He, along with many other wealthy nobles, locked the gates carefully and threw away the keys to keep away from the Red Death. At the time of the plague, the prince hosted a masquerade ball within seven rooms of the abbey, each decorated with a different color. In the party, people were indulging in pleasure. When the black giant bell sounded, guests became thoughtful and pale. However, after the bell, they continued to sing and dance cheerfully. In the midst of their revelry, a mysterious figure disguised as a Red Death victim entered and made his way through each of the rooms. Prospero died after confronting this stranger, 
whose "costume" proved to contain nothing tangible inside it; the guests also died in turn. "And the only things left in the castle were Darkness and the Red Death." [3]

In The Masque of the Red Death, the effect of "terror" was set in advance. In order to achieve this effect, Poe carefully designed and arranged details. He used a large number of color words which had symbolic meanings in the novel. Through the usage of these color words, Poe realized the terror effect he had presupposed, making images fit with the theme of this novel, and offering readers a luxurious visual feast. Using this stimulus, effect of terror in The Masque of the Red Death was vividly presented.

Red. The story took place at the time of plague. In order to enhance the horror effect of the story, Poe chose the title of The Masque of the Red Death, which successfully attracted readers' attention. Red symbolizes blood and violence. The combination of red and disease reminds readers of these horrible, bloody scenes after red death. "Red" is the color of plague. As Poe mentioned in the novel, "red blood is the symbol of terror". [4] As a matter of fact, the disease of "Red Death" was coined by Poe, which was actually the raging plague of Black Death in Europe. Poe replaced black with red with unique intent. In the beginning of the novel, he used "red" to indicate the theme of the story: blood and death.

In addition to the plague of Red Dead, Poe also described the figure of "Red Death" in the party. The red devil was portrayed as a visible and tangible man. "The tall thin figure of the stranger was dressed from head to foot in the white clothes of the dead. And the mask over the face was frighteningly real - it was the face of a dead man. Worse still, the face and the body were covered with red, horrible blood!" [5] In fact, apart from the Red Death, each man and woman was dressed like a terrible dream. Some of their clothes were beautiful and fantastic, while others were ugly, strange or frightening. But no matter how weird they dressed, they could not compete with the Red Death. The shock came from their inner hearts, and no one could overcome it. The Red Death with the simplest dress zapped revelers back to reality, and let people feel fear and panic.

Blue. In general, blue expresses feelings like distance, quiet and detachment. It is also used to describe people's bad mood. The word of blue in expressions like "in a blue mood" and "to have the blues" means "depressed" or "bad luck"; while "blue Monday" can be explained as "unlucky Monday".[6] In the novel, the first room was a blue one. All ornaments and windows of this room were blue. In fact, revelers were happy to go in and out of this room. It was the symbol of people's mental status at the initial state of plague -- depression, but not being affected by this emotion. The layout of this room presented a false impression, like the illusion which could comfort people in a movie. This arrangement catered to all people at the party. Instead of facing the plague, revelers chose to suppress their inner depression and anxiety through the calm and detachment on surface. It was a hint foreshadowing their shock when the Red Death appeared.

Purple. The second room had purple ornaments and tapestries; here the panes were purple like lotus. Purple represents noble and wealth, contrasting with the melancholy of the first room. When going into the room, revelers instantly forgot their troubles, indulged themselves in the glory brought by their noble status. In this country of plague, they enjoyed their superiority for the last time before they died. This was in accordance with the original intention of the prince: all joy and peace were inside the wall, while the Red Death was outside of the wall. It was estimated that only the prince could think out this design. He was foolish enough to believe that the crown could keep the disease out of the wall. He created a vision for his guests. Here, Poe used the color of purple to criticize and satirize the prince for his pride and ignorance.

Green. Green is often used to describe people who are lack of experience, training and knowledge. For instance, "green hand" means "no experience". In addition, green is also used to indicate "jealous" and "envy". "Green with envy" means extremely jealous. The third room in the novel was green, which meant ignorance. It was a satire on people inside the wall. The death was approaching, while the revelers were indifferent and self-deceiving. Although there was a moment, when the giant bell made crisp and melodious sound, people were awakened, nervously meditating. However, after the bell, peacefulness came back, and people continued to sing and dance to extol the good times. 
Because of their ignorance and self deception, when the real death comes, all revelers could do nothing but opening their mouths and waiting in fear.

Orange. Orange symbolizes the vitality of life. It was of special intention for Poe to decorate the fourth room with orange color. People at the party could not stop their inner fear, even though they tried to dress themselves, dance frantically with the accompaniment of the band, beat excitedly with vibrant hearts, and laugh lively and cheerfully. The vitality on the surface could be explained as the emptiness of their heart. On the surface, they behaved calmly. But in fact their hearts waved uneasily. This strong contrast between the bright color of vitality and the dark color of death enhanced the terror effect.

White. In western culture, white symbolizes beauty, cleanliness and purity. It was the illusion that clouded all the revelers. When they stepped into the white room, they mistakenly believed that they had been saved. But the death was slowly approaching. In fact, after the carnival, it was the trial of death that was waiting for them, rather than redemption. Thus, when the agent of death, the "Red Death" came, their fear surged like flood after the dike broke. For people at the party, when Red Death, the devil they did not dare to think of for a long time, suddenly appeared in front of them, it was useless to deceive themselves any more. Their inner fears reached to zenith.

Violet. From orange, the symbol of vitality to white, the symbol of death, and then to violet, the symbol of later years, the mentality of revelers was changing. At first they used illusion to escape from depression, and then they chose self deception, finally the alarm of death went off. Different from purple which indicates rights and wealth, violet implies the twilight years and the cycle of life. But in fact, for these revelers, death in this way was luxurious. Young and strong knights, fashion ladies and the arrogant prince were unable to escape from the Red Death. Here, the natural death was contrasted with the death of pain and suffering, exposing revelers' fear of Red Death.

Black. In fact, black is inseparable with red. The disease of Red Death, which ran through the full text, was actually the Black Death. As the darkest color, black symbolizes death, suffering and sorrow. "The black Friday" is regarded as the most dangerous day. Black is often associated with evil and devils. The color of black appears frequently in the novel. Against the west wall stood a huge black clock. Every hour it chimed loudly, deeply and clearly, filling the castle with its long, gloomy sound. To revelers, it was the bell of death. The room at the west end was described with most details. "The black carpet and walls seemed full of gloom, and the deep chimes of the black clock sounded even more frightening." Here, Poe perfectly combined the two colors of red and black, offering readers with visual shocks. No one dared to enter this room, since it was strange, horrible and breathtaking; no life could escape from this room. The terror effect was perfectly created. Darkness and blood, evil and death were all presented in this room. People's fear of death was magnified until the last moment. When the prince fell upon the black carpet, revelers summoned their courage to go into the black room. But they found no visible corpse under the cloth. At the end of this novel, the only one left in the castle was Red Death. The theme of the story was emphasized again, and the terror effect reached to zenith.

\section{Conclusions}

Edgar Allan Poe successfully used color words in the novel The Masque of the Red Death and achieved the Effect Theory. Through the usage of color words which have symbolic meanings, Poe offered readers a luxurious visual feast. Using this feast, Edgar Allan Poe perfectly explained his literary creation concept; through the careful selection of color words, the pre-established terrorist effect was realized to the largest effect. In fact, in addition to the visual horror, Poe also moved readers' mind from a deeper level, evoking their fear of death and thinking about life. In today's social reality lake, when pursuing material interests and sovereign rights, we should draw lessons from The Masque of the Red Death. The story can be used as a mirror to detect the "Red Devils", "Blue Devils", "White Devils" $\cdots$ around us. 


\section{References}

[1] G.R. Thompson, The Selected Writings of Edgar Allan Poe, WW. Norton \& Company, New York, 2004.

[2] N. Sheng, American Literature in Twentieth Century, Peking University Press, Beijing, 1993.

[3][4][5] Y.L. Chen. et al. (Trans.), Collection of Edgar Allan Poe's Novels, Chinese Books Publishing House, Beijing, 2006

[6]X.Y. Wang, Different meanings of color words in English and Chinese, J. Modern Enterprise Education. 12 (2014). 